\title{
A Review of Deviant Nonprofit Groups
}

\author{
Seeking Method in Their Alleged 'Madness-Treason-Immorality'
}

Author: David Horton Smith

This book studies the deviant form of Nonprofit Groups (NPGs), mainly volunteer-based associations, but occasionally paidstaff-based nonprofit agencies. A Deviant Nonprofit Group (DNG) is defined as "a Nonprofit group that deviates significantly from certain moral norms of the society" (Smith, Stebbins, \& Dover, 2006, p. 68). The aim is to develop and present an empirically grounded theory with eighty-three hypotheses about many of the key analytical features or operational and structural characteristics of DNGs. Such DNGs were usually voluntary associations with memberships and usually run by volunteers, not nonprofit agencies without memberships and usually run by paid staff (Smith, 2017a). The total theory may be termed a Grounded General Theory of DNG Operation-Structure. The book is based on an extensive review and qualitative content analysis of about 26 o published research documents representing twenty-five commonlanguage (vernacular) purposive-goal types of DNGs (vs. analytical-theoretical types, which do not exist in detail). Moral norms are the broad, emotionally charged, customary directives concerning what is right and wrong, by which members of a community or society implement their institutionalized solutions to problems significantly affecting their valued way of life (Stebbins, 1996, pp. 2-3). All the grounded hypotheses reported here were supported by...

\section{See More}

\section{Readership}

Anyone interested in the field of Voluntaristics worldwide, academics and researchers in anthropology, sociology, political science, economics, and psychology, and those interested in Area studies, the social professions, and history. 
David Horton Smith (Ph.D. Harvard University, 1965) is Research 04-40014-6 List price and Emeritus Professor of Sociology, Boston College, USA. Founder (1971) of the Association for Research on Nonprofit Organizations and Voluntary Action/ARNOVA (www.arnova.org) and NVSQ, he is founding editor of this journal.

For more information see brill.com

Order information: Order online at brill.com +44330 3330049 | customerservices@brill.com Submission information: brill.com/authors

Titles published by Brill | Fink, Brill | mentis or Brill | Schöningh: +49(o)71 5413279216 | brill@brocom.de 